This document was prepared in conjunction with work accomplished under Contract No. DE-AC09-96SR18500 with the U. S. Department of Energy.

\title{
DISCLAIMER
}

This report was prepared as an account of work sponsored by an agency of the United States Government. Neither the United States Government nor any agency thereof, nor any of their employees, nor any of their contractors, subcontractors or their employees, makes any warranty, express or implied, or assumes any legal liability or responsibility for the accuracy, completeness, or any third party's use or the results of such use of any information, apparatus, product, or process disclosed, or represents that its use would not infringe privately owned rights. Reference herein to any specific commercial product, process, or service by trade name, trademark, manufacturer, or otherwise, does not necessarily constitute or imply its endorsement, recommendation, or favoring by the United States Government or any agency thereof or its contractors or subcontractors. The views and opinions of authors expressed herein do not necessarily state or reflect those of the United States Government or any agency thereof. 


\section{Integration Strategy for DB-MHR TRISO Fuel production in conjunction with MOX Fuel production}

by

DAVID MCGUIRE

Westinghouse Savannah River Company

Savannah River Site

Aiken, South Carolina 29808

Additional Authors:

This paper was prepared in connection with work done under the above contract number with the U. S. Department of Energy. By acceptance of this paper, the publisher and/or recipient acknowledges the U. S. Government's right to retain a nonexclusive, royalty-free license in and to any copyright covering this paper, along with the right to reproduce and to authorize others to reproduce all or part of the copyrighted paper. 


\title{
Integration Strategy for DB-MHR \\ TRISO Fuel production in conjunction with MOX Fuel production
}

\author{
D. H. McGuire \\ Westinghouse Savannah River Company \\ Savannah River Site
}

September 30, 2005 


\section{CONTENTS}

EXECUTIVE SUMMARY ........................................... 3

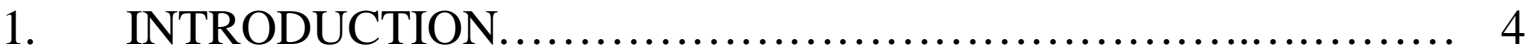

1.1 Strategy Overview

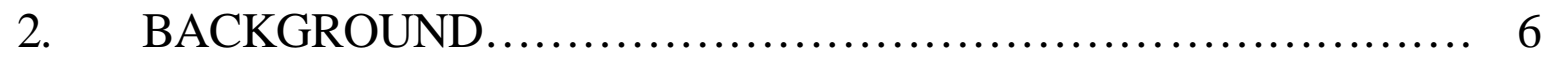

$2.1 \mathrm{MOX} / \mathrm{LWR}$

2.2 TRISO/MHR

3. SYNERGIES ............................................... 7

4. DEVELOPMENTAL AREAS ................................. 8

5. RECOMMENDED INTEGRATION STRATEGY................ 9

6. CONCLUSION - OBJECTIVES vs. STRATEGIES _............. 11

ACRONYMS ..................................................... 14

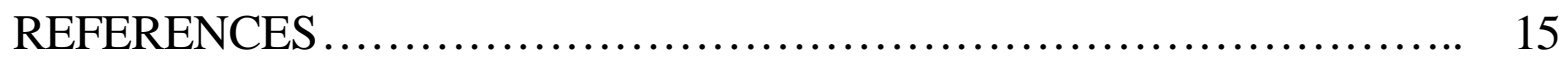




\section{EXECUTIVE SUMMARY}

One of the nuclear power options for the future involves the evolution of gas cooled reactors to support the likely high temperature operations needed for commercial scale hydrogen production. One such proposed option is to use a Gas Turbine Modular Helium Reactor fueled with uranium based TRISO (coated particle) fuel. It has also been suggested that such a MHR could be operated in a "Deep Burn" manner fueled with TRISO fuel produced from recycle spent nuclear fuel. This concept known as a DBMHR must withstand significant development and fuel fabrication cost to be economically viable. The purpose of this report is to consider and propose a strategy where synergy with a parallel MOX fuel to LWR program provides economic or other advantage for either or both programs.

A strategy involving three phases has been envisioned with potential for economic benefit relative to a stand-alone TRISO/DBMHR program. Such a strategy and related timing will ultimately be driven by economics, but is offered here for consideration of value to the total AFCI program.

Phase I Near-term. Conventional spent fuel aqueous processing, MOX fuel fabrication, and use of present and future LWR/ALWR's with objective of a "Continuous Recycle" mode of fuel cycle management.

Phase II Intermediate. Augmentation of LWR/ALWR industry with MHR deployment as justified by hydrogen economy and/or electrical demand.

Phase III Long-term. Introduction of DBMHR's to offer alternative method for transuranic destruction and associated repository benefits, in addition to Phase II benefits.

The basic philosophy of this strategy appears sound. However, the details of the technology plans and economic evaluations should receive additional detail and evaluation in the next fiscal year as funding can support. 


\section{INTRODUCTION}

"Hydrogen production may be a new market for nuclear power, comparable in magnitude to electricity production."

AFCI FY-2005 Comparison Report May 2005

The growing demand for electricity in the U.S. coupled with a need to develop alternative fuel sources [for transportation] and a need to de-emphasize our reliance on fossil fuels [lower greenhouse gas emissions and energy security] will likely result in corresponding growth in nuclear power. Alternatives to the current spent fuel disposition strategy have suggested that the need for additional high level waste repositories can be avoided despite the anticipated growth in nuclear power. A strategy is needed that meets the objectives of efficient electrical production, alternative fuel source development, and reduction of the spent nuclear fuel inventory will require a diverse mix of nuclear technologies. Additional strategic objectives include minimal project capital requirements, technological assurance, and acceptance by the commercial nuclear industry. This report presents a strategy intended to support the following objectives:

- Abundant and efficient electricity production from nuclear power ○ Lower dependency on fossil fuels

- Benefits to high level waste repository $\circ$ Volume and heat load reduction

- Development of alternative fuel source [hydrogen]

- Acceptable project capital expenditure

- Technology maturity and/or technological assurance

- Attractive to nuclear industry (profitable)

It is wise to consider numerous nuclear fuel cycle for meeting all of these objectives. A strategic integration of mature nuclear technologies coupled with present and future advancements in separation techniques and nuclear fuel development is best suited to accomplish all of the strategic objectives. Two specific fuel cycle options are addressed in this report. The first is to reprocess the existing inventory of spent nuclear fuel and recycle the fissile material as a MOX fuel in LWRs (ALWRs). The second option considers use of recycled fuel in a TRISO form as fuel in Gas Cooled Modular Helium Reactors (MHRs). This report focuses on the development of a strategy to make synergistic use of these options in cost efficient manner.

It is important to note that this strategy is focused on the synergy from recycle of spent fuel to LWRs and MHRs. Availability of fast reactors or other Gen IV reactors is deemed beyond the horizon of this application, but not incompatible.

\subsection{Strategy Overview}

A three phased approach is recommended that integrates proven fuel reprocessing techniques with advanced separations processes and existing LWR technology, along with longer-term plans for the demonstration and subsequent deployment of Modular Helium Reactors, and eventually the usage of MHRs for deep burn of the transuranics contained in the spent fuel. 
Phase I Timing: Near-term, starting as soon as 2015.

- Assumes success in current AFCI development activities for separations and fuel fabrication research

- Begin processing of spent fuel into MOX fuel (Pu/Np) and MOX targets $(\mathrm{Am} / \mathrm{Cm})$.

- Use only LWRs and ALWRs for transmutation.

- Continuous recycle of spent fuel - with only fission products sent to the repository.

- $\mathrm{Pu} / \mathrm{Np} \& \mathrm{Am} / \mathrm{Cm}$ inventories reach near equilibrium ("no net production")

- Ultimate goal is "Sustained Recycle" using fast breeder reactors to convert waste $\mathrm{U}$ to fuel when cost/availability of natural $\mathrm{U}$ becomes uneconomical.

Phase II Timing: After TRISO fuel and MHR demonstrations have been successfully completed and economic justification can support initial growth of MHRs.

- Augmentation of LWR/ALWR industry with MHR deployments

- MHRs deployment assumed driven by increased electrical conversion efficiency in addition to hydrogen production capability

- Initial TRISO fuel use limited to Uranium-based fuel only (UOx, UCO)

- UOx/UCO spent TRISO fuel is recycled into MOX in lieu of repository disposal

Phase III Timing: To follow the period where the MHR economy is well established, TRISO transmutation fuel fabrication and deep burn operation in an MHR have been demonstrated.

- Will be driven on economic \& repository impact evaluation of total fuel cycle

- DB-MHRs offer alternative method for transuranic destruction, and repository benefits.

- TRISO driver fuel $(\mathrm{Pu} / \mathrm{Np})$ and Transmuter fuel $(\mathrm{Am} / \mathrm{Cm})$ are introduced into the MHR fuel cycle

- Spent TRISO fuel from this phase is disposed in the repository, or alternatively further processed for supplement to MOX recycle or as feed for a fast reactor or an accelerator driven system. 


\section{BACKGROUND}

\subsection{LWR/ALWR background and future strategy}

A recent study (Ref. 2) summarized three potential methods of recycle for actinide partitioning and transmutation that could be used in near-term and future actinide management systems. In the "Continuous Recycle" approach (Fig. 1) all actinides are recycled continuously and only fission products are sent to the repository. Thus, the maximum repository lifetime is obtained.

\section{Figure 1 Continuous Recycle (Phase I goal)}

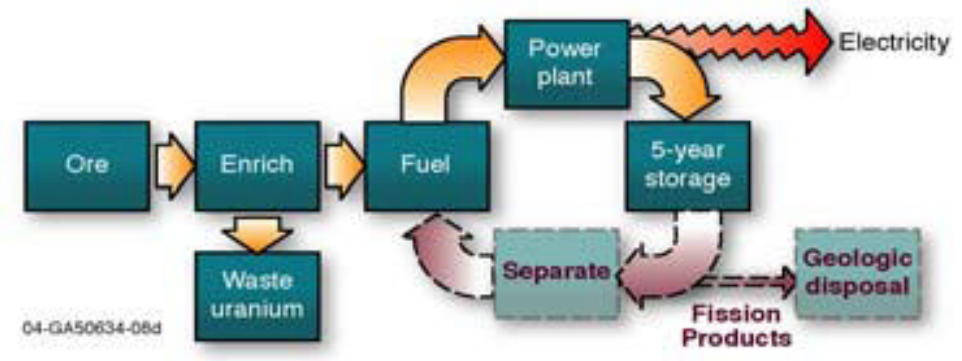

This approach capitalizes on the technology maturity of aqueous separations and LWR operations, and is a simplistic illustration of the Phase I approach.

\subsection{TRISO/MHR background \& justification}

The concept, advantages and developmental needs for the fabrication of TRISO particle fuel and subsequent burn in Modular Helium Reactors (MHR) are well characterized in reports by General Atomics and Oak Ridge National Laboratory. Specifically, references 3, 4, and 5 summarize the process of TRISO fuel fabrication and deployment of MHRs. These reports provide significant detail of the technical attributes of TRISO fuel as being developed for use in a Very High Temperature Reactor (VHTR). These reports, in addition to prior evaluations of TRISO application to transmutation fuels by GA, provide the background to suggest optimizing the nuclear fuel cycle by incorporating a TRISO/MHR segment into the overall strategic approach in parallel with a fuel cycle using recycled MOX fuel in LWRs.

Excerpts from these reports: 


\section{GLOBAL report on SNF Characterization for a VHTR (Ref. 1)}

Recently, the US-DOE funded a fuel cycle study to determine the feasibility of a oncethrough VHTR to meet the cycle length and burnup goals within acceptable design ranges. A Prismatic Modular Reactor design based on the GT-MHR annular core design was evaluated. A two-batch core design was found to meet the stringent requirements found in the study. The fuel cycle performance of the VHTR and its spent fuel characteristics (quantity, composition, decay heat, and radiotoxicity) was evaluated using this 2-batch core design, and compared favorably to those of conventional PWRs.

\section{ORNL report on TRISO-Coated Fuel Processing (Ref. 3)}

High-temperature gas-cooled reactors may be deployed in the next $\sim 20$ years to (1) enable the use of highly efficient gas turbines (HTGR) for producing electricity and (2) provide hightemperature process heat for use in chemical processes, for example the production of hydrogen for use as clean-burning transportation fuel. Also, HTGR fuels are capable of significantly higher burn- up than light-water reactor (LWR) fuels or fast-reactor fuels; thus, the HTGR fuels can be used efficiently for transmutation of fissile materials and long-lived actinides and fission products, thereby reducing the inventory of such hazardous and proliferation-prone materials. The "deep burn" concept is an example of this capability.

In order to fulfill the promise that TRISO fuels and deployment of MHRs have to offer, there are numerous developmental activities that must first be completed (refer to Section 4). The uncertain timetable for completing these developmental actions coupled with the existing fleet of LWRs already in service make the case for a Phase II approach previously highlighted.

\section{SYNERGIES - MOX/LWR and TRISO/MHR}

Phase I is assumed to be justified and progress through implementation. All work on TRISO/MHR application will be essentially independent of the effort in the MOX/LWR arena. However, as the transition from Phase I to Phase II progresses, there will be opportunities (and need) for cost and operability advantages through effective integration of fuel cycle operations, infrastructure, equipment and facilities.-Coupling of functionalities may have fuel cycle advantages that potentially increase the economic attractiveness of a TRISO/MHR option.

- Shared facilities. Processing the existing (and future) spent nuclear fuel produced from LWRs could be accomplished in a common separations facility that could produce a product acceptable for both MOX and TRISO fuel fabrication. (This synergy would be particularly apparent in the Phase III scenario.) Even if this synergy required additional capacity or added production lines relative to a separations facility dedicated to MOX only, the result should be a significant cost avoidance (in terms of total project capital) for the single facility versus two separate facilities dedicated to MOX and TRISO fuel fab, respectively.

- A separate head-end would be required for the pre-treatment of the spent TRISO fuel, but after removal of the coating material and kernel dissolution then the spent TRISO fuel material can be blended appropriately within the LWR spent fuel separations plant. 
- Uranium Re-enrichment. The uranium that is partitioned from the processing of spent LWR fuel can be reused in the fabrication of uranium-based TRISO fuel, or recycled into LWR-MOX fuel.

- It is assumed that a sound MHR economy would be demonstrated before the additional significant expense of remote transmutation and driver TRSIO fuel fabrication could be justified. Therefore, the primary Phase II synergy results from the potential to recycle the spent UOx TRISO fuel through the same MOX spent fuel treatment facility avoiding the cost of repository exposure. It is necessary however that the economics of TRISO recycle vs. direct disposal be evaluated.

- Phase II: By recycling 100\% of the spent TRISO fuel back into MOX, an overall fuel cycle concept of continuous recycle can be maintained whereby material directed to the repository is limited to fission products and secondary wastes (e.g.- fuel cladding, carbon and TRISO coating/compact materials)

\section{DEVELOPMENTAL AREAS}

The large-scale production of LWR UOx fuel is a very mature industry in the U.S., and spent fuel reprocessing for the production of MOX fuel has been demonstrated for decades internationally. The production and use of TRISO particle fuel is a less mature industry. Fabrication of uranium-based TRISO particle fuel at a scale to supply an entire MHR core was demonstrated during the 1970s (Fort St. Vrain). Coated particle fuel fabrication facilities have been in operation in other countries (Germany, Russia, Japan) with successful quality and performance results (Ref. 5). Based largely on this previous experience, it is envisioned that the Phase II development, demonstration and deployment of MHRs burning UOx or UCO TRISO fuel can be achieved with a higher degree of technical assurance and more economically than comparative program for Phase III deployment.

Technical issues that are applicable to Phase II are:

- Waste consolidation to produce a compact graphite-carbon high-level waste form of high integrity that meets repository waste containment criteria (including TRISO coating waste as appropriate).

- Automated high-speed NDE methods are needed to support economical commercialization of TRISO fuel production. (Reference 5)

While the deep burn concept has been extensively analyzed with promising results, there remains significant development work followed by scale-up demonstrations before any widescale deployment of DB-MHRs is achievable. Reference 4 identifies several technical issues to resolve as part of the roadmap to deployment of Gas Cooled Reactors using TRISO fuel and the deep burn concept. Each of the following is a precursor to Phase III implementation:

- Fabrication of high quality TRISO containing plutonium and other MA's

- Irradiation of Pu-containing TRISO to $>50 \%$ burnup

- Confirmation of TRISO performance in repository environment with unirradiated fuel 
- Analyses of DB-MHR core designs to confirm required nuclear, thermal, and source term characteristics

Programmatic activities were also identified:

- Establishment of a lab-scale DB-MHR fuel fabrication facility

- Irradiation testing/qualification of fuel capsules under DB-MHR conditions

- Characterizing kernel chemistry and behavior under repository conditions

- DB-MHR core design program (fuel cycle studies)

- DB-MHR fuel facility in operation in the U.S.

- Systems Analysis support (modeling) to quantitatively evaluate the various duatpath scenarios (MOX \& TRISO) at various rates, fuel and core loadings, timelines, etc.

Other Phase III developmental needs

1. Cost-effective TRISO fuel fabrication on a commercial-scale (DF and TF).

2. TRISO kernel/particle design including isotopic mix in order to achieve sufficient TRU destruction such that a single-pass deep burn yields spent TRISO fuel that is beneficial to repository space and thermal load management. (Required for one option of Phase III implementation.)

3. TRISO waste form proven as an effective containment of residual radionuclides that meets repository storage requirements.

4. Physical demonstration of developmental items \#3 and \#4.

\section{RECOMMENDED INTEGRATION STRATEGY}

The recommended phased integration strategy set forth in this report combines conventional aqueous separations techniques, fuel choices that are compatible with the existing fleet of nuclear reactors, and future optimization by capitalizing on developmental efforts well underway with respect to TRISO fuel and gas-cooled reactor technology. In considering the expected growth of nuclear power over the remainder of this century, it is assumed that a robust hydrogen economy of the future will justify the demand/need for some number of MHRs to support hydrogen production in addition to nuclear power production. The actual extent of the MHR fleet will depend on economics and the demand driven by the hydrogen economy.

The Phase II scenario capitalizes on the primary advantages of high temperature gas-cooled reactor technology (Ref. 3, ORNL report):

- Enable the use of highly efficient gas turbines for producing electricity, and

- Provide high-temperature process heat for use in the production of hydrogen (for use as clean-burning transportation fuel)

An added attractive feature of the Phase II integration strategy is the potential to optimize the fabrication expense of uranium-based TRISO fuels by utilizing prior UOx/UCO fuel fabrication experience and capitalizing on the cost-avoidance by re-use of partitioned uranium. 
The Phase II integration strategy is illustrated in Figure 2.

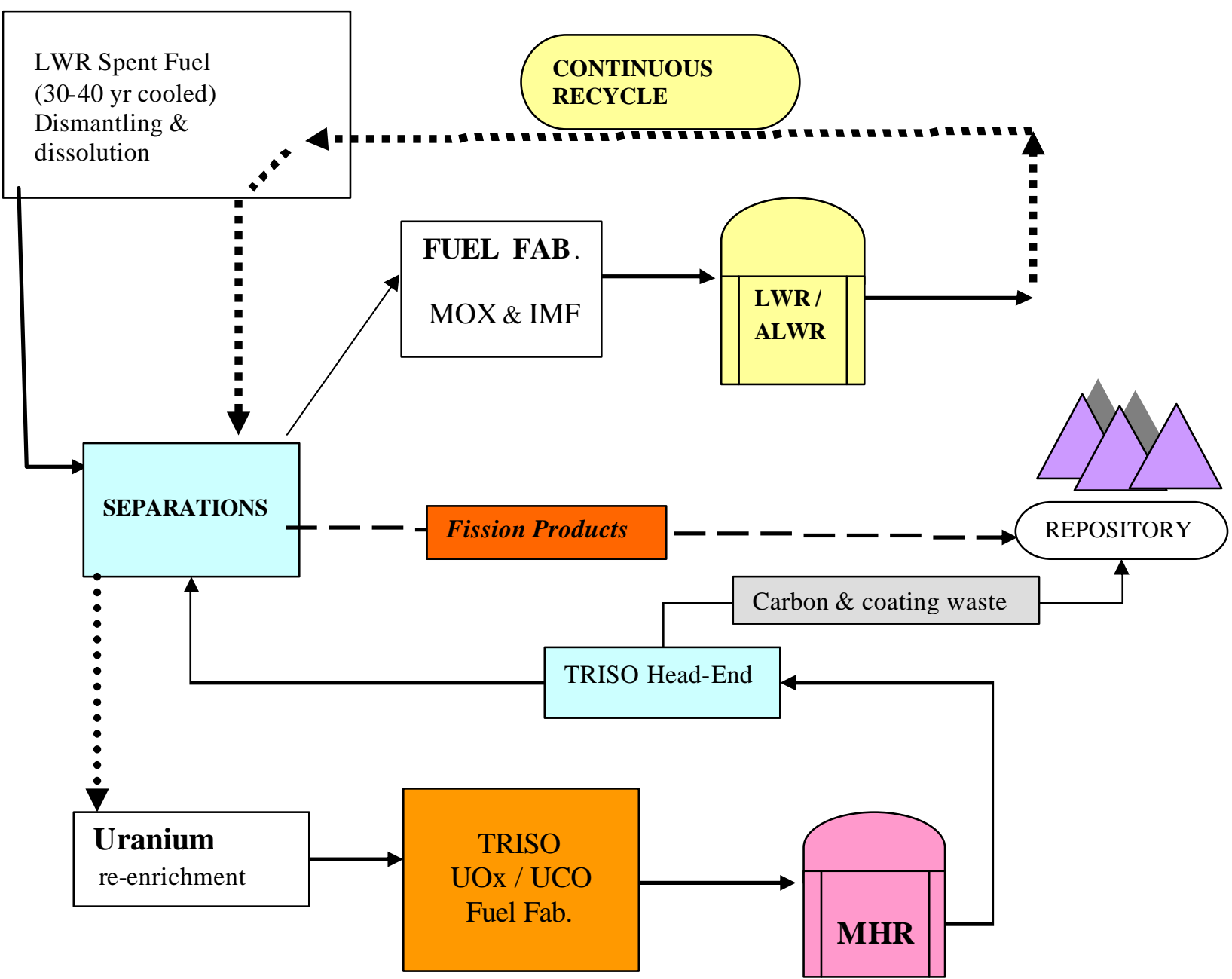

Figure 2. Phase II Integration Strategy

Phase III Integration Strategy - As mentioned previously, demonstration of a sound MHR economy should be accomplished before the significant additional expense of remote transmutation and driver TRSIO fuel fabrication could be justified. Reference 4 (pages 7076) provides a descriptive and viable approach to a possible scenario for MHR and deep burn deployment in the US. It is recommended that this reference be consulted for details. 


\section{CONCLUSIONS - OBJECTIVES vs. STRATIGIES}

A future, robust hydrogen economy could be the driving force that justifies a need for Modular Helium Reactor deployment in conjunction with LWR/ALWR utilization. Longerterm, utilization of the same MHRs for "deep burn" of waste transuranics could benefit the high level waste repository and closure of the nuclear fuel cycle. In order to enhance the se opportunities, emphasis should be placed on these areas:

- Optimization of TRISO fuel fabrication at commercial scale

- Quality control and assurance of the TRISO particle in terms of both reactor performance and meeting repository waste form criteria.

- Demonstration of TRISO particle performance

The following table summarize s how the three phase strategy, and the synergies offered by integrating MOX/LWR with TRISO/MHR technologies, fulfills the functional requirements of all the stated objectives.

\section{Table 1. Strategies vs. Objectives}

\begin{tabular}{|c|c|}
\hline OBJECTIVE & STRATEGIC APPROACH \\
\hline $\begin{array}{l}\text { Abundant and efficient electrical power } \\
\text { production from nuclear } \\
\text { • Lower dependency on fossil fuels }\end{array}$ & $\begin{array}{l}\text { Phase I } \\
\text { Near-term deployment of new LWRs and } \\
\text { ALWRs to meet growing electrical demand. } \\
\text { Phase II and III } \\
\text { Longer-term deployment of MHRs to provide } \\
\text { higher electrical conversion efficiency, and to } \\
\text { supply hydrogen demand. }\end{array}$ \\
\hline $\begin{array}{l}\text { Benefits to high level waste repository } \\
\text { - Volume and heat load reduction }\end{array}$ & $\begin{array}{l}\text { Phase I } \\
\text { Only fission products go into repository. } \\
\text { Uses only existing wet/dry storage - no new } \\
\text { capacity needed. } \\
\text { Phase II } \\
\text { No significant heat load addition from the } \\
\text { coating and carbon wastes from TRISO } \\
\text { recycle. } \\
\text { Phase III } \\
\text { Deep burn destruction of transuranics reduces } \\
\text { spent fuel decay heat [due to actinides], } \\
\text { which benefits the repository in terms of } \\
\text { nuclear waste loading. }\end{array}$ \\
\hline
\end{tabular}




\begin{tabular}{|c|c|}
\hline OBJECTIVE & STRATEGIC APPROACH \\
\hline $\begin{array}{l}\text { Development of alternative fuel source } \\
\text { [hydrogen] }\end{array}$ & $\begin{array}{l}\text { Phase II and III } \\
\text { High temperature of the MHR yields process } \\
\text { heat for use in the production of hydrogen }\end{array}$ \\
\hline Acceptable project capital expenditure & $\begin{array}{l}\text { Phase I } \\
\text { Capitalizes on existing LWR fleet and mature } \\
\text { technologies. } \\
\text { Phase II } \\
\text { Capitalizes on synergies of shared facilities } \\
\text { and reduced TRISO fuel cost by reuse of } \\
\text { Uranium. Scope of MHR deployment } \\
\text { depends on cost/benefit driven by hydrogen } \\
\text { economy. }\end{array}$ \\
\hline $\begin{array}{l}\text { Technology maturity and/or technological } \\
\text { assurance }\end{array}$ & $\begin{array}{l}\text { Phase I } \\
\text { Aqueous separations, LWR usage and MOX } \\
\text { fuel fabrication are all previously } \\
\text { demonstrated technologies with extensive } \\
\text { operational track record. } \\
\text { Advanced separations techniques that } \\
\text { underpin "continuous recycle in LWRs" are } \\
\text { well understood, already demonstrated at lab } \\
\text { scale, and/or have well planned } \\
\text { developmental and demonstration plans. } \\
\text { Phase II } \\
\text { TRISO UOx fuel previously manufactured at } \\
\text { large scale, and GCR operation has been } \\
\text { demonstrated. } \\
\text { Other TRISO and MHR developmental } \\
\text { needs, including spent TRISO recycle, are } \\
\text { well understood with established R\&D plans. } \\
\text { Phase III } \\
\text { Principles of design for DB TRISO particles } \\
\text { are known. Pu-oxide particles have been } \\
\text { irradiated to 70\% burnup with good success. } \\
\text { Current fabrication techniques assumed } \\
\text { capable of meeting DB-MHR quality } \\
\text { requirements. } \\
\text { While DB-MHR developmental needs are } \\
\text { well characterized, the timetable to resolution }\end{array}$ \\
\hline
\end{tabular}




\begin{tabular}{|l|l|}
\hline \multicolumn{1}{|c|}{ OBJECTIVE } & \multicolumn{1}{c|}{ STRATEGIC APPROACH } \\
\hline $\begin{array}{l}\text { (continued) } \\
\text { Technology maturity and/or technological } \\
\text { assurance }\end{array}$ & $\begin{array}{l}\text { may be longer than a Phase I deployment. A } \\
\text { successful Phase II deployment would } \\
\text { augment the progress to Phase III } \\
\text { implementation. }\end{array}$ \\
\hline Attractive to nuclear industry (profitable) & $\begin{array}{l}\text { Phase I } \\
\text { Greatest near-term appeal in terms of } \\
\text { utilization of existing capital assets. }\end{array}$ \\
Phase II \\
$\begin{array}{l}\text { The attractiveness (of MHR deployment) to } \\
\text { industry will be driven by hydrogen } \\
\text { economy, potential cost of recycled fuel in } \\
\text { lieu of uranium, and corresponding profit } \\
\text { potential. }\end{array}$ \\
\hline
\end{tabular}




\section{Acronym List}

DBMHR Deep Burn Modular Helium Reactor

DF

EUOx

Driver Fuel (TRISO particle fuel containing $\mathrm{Pu}-\mathrm{Np}$ )

GCR

Higher enriched UOx

IMF

Gas Cooled Reactor (used interchangeably with MHR in this document)

MA Inert Matrix Fuel (no Uranium)

MHR Modular Helium Reactor

MOX

Mixed Oxide Fuel

PWR

Pressurized-water reactor

SNF

SFTF

TF

Spent Nuclear Fuel (from commercial reactors)

TRU

Spent Fuel Treatment Facility

UCO

Transmuter Fuel (TRISO particle fuel containing Am-Cm)

UOx

Transuranic elements (those heavier than Uranium, esp. Pu, Np, Am, Cm)

Uranium Oxy-carbide fuel

VHTR

Uranium Oxide fuel (enriched with fissile U-235)

Very High Temperature Reactor 


\section{REFERENCES}

1. T. K. Kim, T. A. Taiwo, R. N. Hill, and J. A. Stillman, 'Spent Nuclear Fuel Characterization for a VHTR", Argonne National Laboratory, Proceedings of GLOBAL 2005, Tsukuba, Japan, Oct 9-13, 2005.

2. Emory D. Collins and John-Paul Renier, "Systems Studies of Actinide PartitioningTransmutation Recycle Methods", Oak Ridge National Laboratory, Proceedings of GLOBAL 2005, Tsukuba, Japan, Oct 9-13, 2005.

3. G. D. Del Cul, B.B. Spencer, C.W. Forsberg, E.D. Collins, and W.S. Rickman, “TRISO Coated Fuel Processing to Support High-Temperature Gas-Cooled Reactors", ORNL/TM-2002/156, Oak Ridge National Laboratory, September, 2002.

4. "Workshop on Deep-Burn Destruction of Nuclear Waste using MHR Technology", General Atomics, November 5, 2004 San Diego, CA.

5. “Advanced Gas Reactor Fuel Development and Qualification Program", presented at the Advanced Gas Reactor Technology Course, ANS Summer Meting, San Diego, June 10, 2005 (John Saurwein, General Atomics) 